\title{
Ciência da religião aplicada no curriculo do ensino religioso do estado do Pará
}

\author{
Study of religion applied in religious education curriculum of \\ state of pará
}

Rodrigo Oliveira dos Santos ${ }^{1}$

Sérgio Rogério Azevedo Junqueira ${ }^{2}$

\section{Resumo}

A Ciência da Religião vem se consolidando como disciplina acadêmica na pósgraduação, graduação e como aplicação do Ensino Religioso nas escolas públicas brasileiras. Dessa forma, o presente artigo de orientação bibliográfica e abordagem pós-estruturalista, busca apresentar, considerando o método histórico-comparativo, como vem se construindo as mudanças curriculares no Ensino Religioso paraense. Nessas últimas duas décadas é notável a forte influência da Fenomenologia com enfoque na experiência religiosa, algo que vem sendo revisto e fortemente criticado. Com a aprovação do Ensino Religioso na Base Nacional Comum Curricular, cada Estado pode organizar seus currículos a partir desse documento e da sua própria realidade. Nesse aspecto, na rede estadual de ensino, os professores organizados na Associação dos Cientistas da Religião do Estado do Pará elaboraram seu documento com base na sua ciência de formação e aplicação para o estudo sobre religiões nas escolas públicas.

Palavras-Chave: Ciência da Religião. Ensino Religioso. Currículo. BNCC.

\section{Abstract}

The Study of Religion has been consolidating as an academic discipline in postgraduate, undergraduate and religious teaching in Brazilian public schools. Thus, the present article of bibliographical orientation and post-structuralist approach, aims to present, considering the historical-comparative method, how the curricular changes in the Religious Education of Pará have been constructed. In the last two decades the strong influence of the Phenomenology with a focus on religious experience is remarkable, something that has been reviewed and strongly criticized. With the approval of Religious Education in

\footnotetext{
${ }^{1}$ Doutorando em Ciência da Religião (PUC-SP). Mestre em Educação (UFPA). Graduado em Ciência da Religião (UEPA). Professor de Ensino Religioso na Secretaria de Estado de Educação - SEDUC-PA e na Secretaria Municipal de Educação - SEMEC-Belém; Bolsista CAPES. E-mail: professorcr@hotmail.com

${ }^{2}$ Livre Docente e Pós-Doutor em Ciência da Religião (PUC-SP). Pós-Doutor em Geografia da Religião (UFPR). Doutor e Mestre em Educação pela Pontifícia Universidade Salesiana de Roma. Licenciado em Pedagogia (UNIUBE). E-mail: sergio@ipfer.com.br
} 
Religare, ISSN: 19826605, v.15, n.1, agosto de 2018, p.97-126.

the National Curricular Common Base, each State can organize its curricula from this document and from its own reality. In this aspect, in the state education network, teachers organized in the Association of Study of Religion of the State of Pará elaborated their document based on their science of formation and application for the study on religions in public schools.

Keywords: Study of Religion. Religious education. Curriculum. BNCC.

\section{Apresentação}

O processo de construção do currículo de uma rede estadual é uma tarefa desafiadora, que envolve muitas questões, interesses e sujeitos, que precisam ser previamente avaliados e de certa forma considerados nesse processo de forma que o produto, o currículo, possa orientar a prática docente.

Dessa forma, apresentaremos o processo de elaboração do currículo do Ensino Religioso (ER) do Estado do Pará, sendo possível somente com a Base Nacional Comum Curricular (BNCC) (BRASIL, 2017), pois até então a rede estadual não dispunha de um currículo oficial que orientasse a prática docente desses professores.

As primeiras propostas até o final do século passado priorizavam os dispositivos legais, sendo assim organizados em dois grandes modelos de ER: o modelo confessional, também conhecido como catequético, referia-se objetivamente ao ensino de uma tradição religiosa reconhecida pelo Estado, encontrou base legal para aplicação na Lei de Diretrizes e Bases da Educação Nacional (LDB), a Lei $\mathrm{n}^{\circ} 4.024 / 1961$; e o modelo interconfessional, também conhecido como teológico; visto como o segundo modelo adotado no Brasil a partir da articulação de diferentes confissões cristãs e, posteriormente, de forma mais lenta, assumindo diversas tradições religiosas. Encontrou base legal para sua aplicação na Lei no 5.692/1971.

As tentativas para superação dessa situação não ocorreram com a Lei n⿳o 9.394/1996, já que previa um ER desenvolvido a partir dos modelos confessional e interconfessional, respectivamente, não indo além da proposta de uma 
Religare, ISSN: 19826605, v.15, n.1, agosto de 2018, p.97-126.

educação para religiosidade enviesada nos valores da matriz cultural-religiosa judaico-cristã.

Com a alteração do Art. 33 da LDB, mediante a Lei nº 9.475/97, iniciouse a perspectiva da escolarização, ou seja, buscou-se organizar o ER a partir da própria escola, de seus princípios e pressupostos e não mais das confissões religiosas.

Esse processo continua em andamento e vem ganhando forças com a abertura dos cursos de licenciatura em Ciência da Religião (CR), a partir de 1996, pelos Sistemas e Instituições de Ensino Superior em vários lugares do país, garantindo a formação específica na área de atuação (SANTOS, 2014; SANTOS, SEIBT, 2014), conforme o Art. 62 da LDB (BRASIL, 1996).

A esse aspecto fundamental para o reconhecimento da área (Ciência da Religião) e sua aplicação como componente curricular (Ensino Religioso), tem causado muito impacto, especialmente no contexto paraense aonde a disciplina vem sendo conduzida por um profissional de educação como quaisquer outros e o tratamento curricular, do qual nos propomos aqui a discorrer sobre seu percurso, não tem sido diferente.

Nisso posto, o presente artigo apresenta como objeto de análise o currículo do ER, apropriando-se da pesquisa bibliográfica, de abordagem pósestruturalista e do método histórico-comparativo das propostas curriculares, dos discursos e negociações elegidos nesses documentos, para assim traçar a trajetória do currículo oficial da rede estadual do Pará.

\section{A Ciência da Religião como ciência de referência para formação de professores e aplicação do Ensino Religioso}

Em termos legais ou jurídicos, o ER é compreendido como área de conhecimento (BRASIL, 1998) no Ensino Fundamental (EF), ampliada tal concepção para Educação Básica (EB) (BRASIL, 2010a) e reforçada no EF de Nove Anos (BRASIL, 2010b). 
Religare, ISSN: 19826605, v.15, n.1, agosto de 2018, p.97-126.

Não obstante a isso, o ER vinha sofrendo com a ausência de políticas curriculares e de formação de professores, pois até então não se dispunha de diretrizes para isso, reafirmando por outro lado inconsistências diante da laicidade do próprio Estado, que deixou a revelia dos Sistemas e Instituições de Ensino tal competência.

Essa situação permitiu, por outro lado, que o ER ainda continuasse sob a influência das confissões religiosas, especialmente as cristãs.

A orientação legal que apontava o ER como área de conhecimento, também serviu para acentuar ainda mais esse caráter, situação que começou mudar de forma mais efetiva em 2006 (SENA et al., 2006), quando se tornou consenso entre os estudiosos e pesquisadores do campo no Brasil, que esse componente curricular depende diretamente das pesquisas e resultados da Ciência da Religião (CR), Religionswissenschaft em alemão, área científica e autônoma institucionaliza em 1873 (USARSKI, 2006), bem antes que outras Ciências Humanas, como a Psicologia (1879) e a Sociologia (1892).

A trajetória e instalação da CR no Brasil iniciaram em proximidade com a Teologia, em 1969, de onde não só compartilhou de teorias, métodos e abordagens epistemológicas da referida, como também foi confundida e ainda é com ela, e quem sabe o resultado disso possa explicar a diversidade de nomenclaturas e o amontoado de subdisciplinas de várias áreas de conhecimento, bem diferente daquilo que foi pensado pelos fundadores dessa Ciência (MÜLLER, 1870; WACH, 1924; GRESCHAT, 2005; USARSKI, 2006 e 2013; HOCK, 2010; COSTA, STERN, 2017).

Do mesmo modo, esse aspecto se reproduziu nos cursos de graduação na modalidade licenciatura, iniciados em 1996, com destaque para Santa Catarina e em 2000 no Pará.

Esse cenário sofreu poucas alterações, mesmo que em alguns programas de pós-graduação e graduações em CR estejam fora desses 
Religare, ISSN: 19826605, v.15, n.1, agosto de 2018, p.97-126.

departamentos. Percebe-se que esse aspecto ainda persiste e de alguma forma continua presente orientando os estudos sobre religiões e não para religiões.

As tentativas epistemológicas foram muitas e as mais significativas se resumiram a Fenomenologia da Religião, abordagem teórico-metodológica, que no Brasil sofreu e ainda sofre muito a influência da Teologia, área acadêmica alicerçada sobre os pressupostos da fé de uma tradição religiosa nas suas elaborações metafísicas racionais.

Essa abordagem influenciou os Parâmetros Curriculares Nacionais do Ensino Religioso (PCNER), organizado pelo Fórum Nacional Permanente do Ensino Religioso (FONAPER) em 1996, assim como também as licenciaturas em CR.

As críticas a essa abordagem já vêm sendo realizadas no contexto internacional desde a segunda metade do século passado e apontam certa disfunção intelectual no estudo sobre religiões e não para religiões, que em outras palavras afirmam que "há uma instância própria no interior do ser humano que reage à esfera divina transcendental analogamente a uma caixa de ressonância que, devido a seu material, vibra na mesma frequência de um som produzido próximo a ela" (USARSKI, 2006, p. 34).

É como se os seres humanos possuíssem estruturas predispostas que ao serem acionadas reconhecessem a presença do sagrado como fenômeno universal, único e de certa forma que ultrapassaria a história, abstraindo assim, "do mundo empírico por ativar seu próprio sensus numinis e "treine" sua empatia com o sagrado para se deixar penetrar emocionalmente pelo numinoso e experiênciá-lo" (USARSKI, 2006, p. 50).

Essa apreensão, transportada da cosmovisão judaico-cristã não é compatível com muitas religiões no mundo e no Brasil, especialmente no caso brasileiro em se tratando das religiões de matrizes culturais indígenas e africanas, entre outras. 
Religare, ISSN: 19826605, v.15, n.1, agosto de 2018, p.97-126.

Nesse aspecto, diante da naturalização de uma fenomenologia religiosa, a presente proposta busca se alicerçar na CR e na sua própria estrutura interna, organizada em Ciência da Religião Sistemática ou Ciência da Religião Comparada e Ciência da Religião Empírica ou História das Religiões, para o estudo sobre religiões de forma geral e singular respectivamente.

A abrangência desse estudo garantido pela $C R$ vem sendo renovada com o desdobramento na estrutura interna dessa área autônoma pela Ciência Prática da Religião ou Ciência da Religião Aplicada, sendo a última referência que adotamos para a docência no ER (SANTOS, 2018).

A esse aspecto, já citado na obra de Max Muller (1982), tem sido visto como a saída para um ER científico e laico, em função dos resultados das pesquisas da CR para a escola básica, onde o licenciado em CR é esse docente.

Nesse sentido, a presente proposta como quaisquer outras se fundamenta numa Ciência de Referência, a Ciência da Religião, e seus resultados transmutados asseguram o ER escolarizado, científico e laico nas escolas públicas.

\section{A trajetória do curriculo}

O alinhamento curricular para a prática pedagógico-didática do ER nas escolas paraenses não estava distante da realidade percebida em grande parte do país, que até meados da década passada centrava-se na abordagem interconfessional, priorizando assim a educação da/para religiosidade, com foco no ensino de valores religiosos, especialmente os judaico-cristãs.

As iniciativas mais bem sucedidas partiram da Associação dos Cientistas da Religião do Estado do Pará (ACREPA), fundada em 2007, com a pauta da profissionalização dessa mão de obra qualificada para o ER (BAHIA, SANTOS, 2018).

Ao mesmo tempo em que a ACREPA lutava pelo espaço desse profissional na educação pública local, mediante a entrada de ações jurídicas no 
Religare, ISSN: 19826605, v.15, n.1, agosto de 2018, p.97-126.

Ministério Público Estadual e Federal, assim como nas próprias Secretarias de Educação Municipal (Belém) e Estadual e seus respectivos Conselhos, a preocupação com o que vinha sendo trabalhado com os alunos em termos curriculares nas escolas não se tornou algo secundário para tal Associação.

A ACREPA promoveu em 2011 o I Encontro de Formação e Atualização Docente para o Ensino Religioso e a Elaboração da Proposta Curricular para o Ensino Religioso na Educação Básica para discussão da elaboração de uma proposta curricular, o que possibilitou no ano seguinte a apresentação da mesma no evento da Secretaria de Estado de Educação (SEDUC) do Pará sob o título Currículo da Educação Básica: a política curricular estadual para a educação básica em interface com o contexto sociocultural na diversidade paraense (SANTOS, 2012; SANTOS, SEIBT, 2014).

A proposta, apesar de pronta e publicada não fora oficializada pela SEDUC/PA (SANTOS, 2012).

No final de 2013, assumiu na SEDUC/PA outra equipe de reorientação curricular, que estabeleceu outros parâmetros para a discussão na rede estadual, passando a ser organizada em quatro grandes eixos estruturantes "que se relacionam com os objetos de estudo de cada componente da matriz curricular, resultantes da produção humana no decorrer dos tempos e nos diversos contextos socioculturais" (PARÁ, 2015, p. 10).

Os eixos estruturantes propostos pela Secretaria são: 01. O espaço/tempo e suas transformações; 02. Linguagens e suas formas comunicativas; 03. Valores à vida social e 04. Cultura e identidade.

Dessa forma, os eixos se subdividem em subeixos, que se relacionam aos objetivos da aprendizagem, mantidos na proposta curricular da Secretaria como um todo.

No segundo semestre de 2014 a proposta que compreendia todo o Ensino Fundamental (EF) foi disponibilizada no site da SEDUC/PA para as possíveis contribuições dos professores da rede de ensino. 
Religare, ISSN: 19826605, v.15, n.1, agosto de 2018, p.97-126.

Após esse período de quase um mês para as contribuições dos professores, retornamos os trabalhos para finalização da proposta até o final do referido ano. No início de 2015 a proposta ficou pronta (PARÁ, 2015).

Apesar dessa nova organização, mais uma vez a SEDUC/PA também não oficializou a referida proposta até o final de 2015.

Esse período também esteve marcado pelas discussões em torno BNCC, que teve sua $1^{\text {a }}$ versão publicada em setembro de 2015 e consulta pública disponibilizada até março de 2016.

Com publicação da $2^{a}$ versão da BNCC, em 2016, iniciaram os seminários estaduais, sendo o do Pará realizado em agosto do mesmo ano, do qual um dos autores esteve na coordenação do componente curricular ER com outro professor da rede municipal de Ananindeua (município da Região Metropolitana de Belém (RMB)).

Dessa forma, o ER vinha sendo tratado como os demais componentes curriculares até a sua retirada quando da publicação preliminar da $3^{\underline{a}}$ versão da BNCC em setembro de 2017, mas devido há inúmeras mobilizações de setores eclesiásticos, acadêmicos, profissionais, entre outros ${ }^{3}$, o ER retorna a BNCC na sua $4^{\text {a }}$ versão aprovada em dezembro de 2017, mesmo com algumas ressalvas, devido a Ação Direta de Inconstitucionalidade (ADI) nº 4.439/2010 (BRASIL, 2017a, 2017b).

Após a publicação do texto definitivo da BNCC que abrange a Educação Infantil (EI) e EF, as discussões curriculares na rede estadual se intensificaram, principalmente no primeiro semestre desse ano, no qual todos os componentes curriculares representados por seus coordenadores deveriam realizar as devidas adaptações, considerando as orientações da BNCC.

Também no início de 2018 tivemos conhecimento de que o Ministério da Educação (MEC), instituiu o Programa de Apoio a Implementação da BNCC

\footnotetext{
3 Para saber mais sobre esses movimentos favoráveis e contrários ao ER, assim como a ADI no 4.439/2010 ver Santos (2010, p. 50-62 e p. 350-358). In: BRANDENBURG, L. E.; JUNQUEIRA, S. R. A; KLEIN. R. (orgs.). Compêndio do ensino religioso...
} 
Religare, ISSN: 19826605, v.15, n.1, agosto de 2018, p.97-126.

(ProBNCC), com o objetivo de apoiar financeiramente a implementação dos currículos alinhados a BNCC nos Estados, Municípios e Distrito Federal.

Além de custear assessorias de especialistas, logística de eventos e até impressões, a Portaria no 333, de 05/04/2018 - MEC, ainda estabelece ao redator(a) de currículo - ensino fundamental - componentes curriculares, uma bolsa mensal de até 1.100,00, por 18 meses.

Mesmo que não houvesse restrições na referida Portaria, o ER ficou de fora mais uma vez, deixando assim os redatores da disciplina excluídos das formações, discussões e encontros realizados na capital brasileira em 2018.

Dessa forma, esse tratamento não deveria mais se justificar diante dos avanços em relação ao espaço que a CR vem ocupando tanto na graduação como na pós-graduação, da qual conta com o respaldo do próprio MEC, que recentemente estabeleceu uma Subcomissão para assessorar a Comissão instituída no âmbito da Câmara de Educação Superior (CES), por meio da Portaria n⿳o CNE/CES nº 3, de 01/03/2018, para analisar a necessidade de estabelecer Diretrizes Curriculares Nacionais do curso de graduação em CR . $^{4}$

Após muitas negociações e pressões de vários lados, o Parecer CNE/CP no 12/2018 que trata das Diretrizes Nacionais Curriculares para o Curso de Licenciatura em CR homologado ${ }^{5}$, confirmando a adoção da CR como ciência de referência para a formação inicial de professores de ER.

A demora na definição de políticas nacionais ou na resolução de problemas pelos setores competentes vinculados ao MEC, por um lado, ainda permite que esse tipo de situação aconteça, enquanto por outro, motiva os profissionais já licenciados a ocupar esses espaços, assegurados nas leis educacionais.

Foi isso que aconteceu no Pará, sob a responsabilidade da ACREPA que em fevereiro de 2018 realizou o IV Encontro de Professores de Ensino Religioso do

\footnotetext{
${ }^{4}$ Subcomissão estabelecida pela Portaria CNE/CES no ${ }^{6}$, de 26/04/2018. Publicada no Boletim de Serviço $n^{\circ}$ 18, de 11/05/2018, pp. 18 e 19.

${ }^{5}$ Parecer homologado pela Portaria n⿳o 1.403, publicada no D.O.U., de 28/12/2018, seção 1, p. 131.
} 
Religare, ISSN: 19826605, v.15, n.1, agosto de 2018, p.97-126.

Estado do Pará: Ciência da Religião e Ensino Religioso na Base Nacional Comum Curricular, na Universidade Federal do Pará (UFPA), com ampla participação de pesquisadores e professores de outros Estados, que contribuíram significativamente para o currículo do Pará. Dentre os Estados representados estavam presentes Acre, Amapá, Amazonas, Minas Gerais, Paraná e São Paulo.

O evento teve como objetivo geral a finalização do currículo da rede estadual de ensino, discutido com ampla participação dos professores de ER do Pará e outros Estados, sendo depois apresentada à SEDUC/PA como proposta a ser oficializada.

Dos Estados que temos conhecimento, o Pará foi um dos primeiros a inaugurarem a discussão do currículo do ER com base na BNCC após a sua oficialização, assim como o primeiro a disponibilizar o currículo para conhecimento de todos no espaço acadêmico, demonstrando a pertinência da função social que essa disciplina ocupa entre os outros componentes curriculares na formação integral do cidadão com o estudo não normativo sobre religiões nas escolas.

\section{Organização do curriculo}

Apesar de estar (um dos autores) desde o início na coordenação das propostas, organizando e contribuindo com aquelas relacionadas ao ER, vários outros professores de ER da rede estadual e municipais também estiveram contribuindo, sempre representando a ACREPA.

Além deles, contamos com apoio de outros pesquisadores de vários lugares do Brasil para revisão, análise crítica e contribuições. Um grande momento para isso ocorreu durante o IV Encontro de Professores.

Podemos assim destacar quatro momentos importantes para o nosso currículo. O primeiro se deu com o minicurso: Diretrizes curriculares nacionais para o ER: uma proposta fundamentada na Ciência da Religião, onde Costa (2015) apresentou sua proposta a partir do texto que deu o mesmo nome ao minicurso, 
Religare, ISSN: 19826605, v.15, n.1, agosto de 2018, p.97-126.

destacando que "as religiões e religiosidades devem ser vistas como expressões culturais, sociais e psicológicas, sendo fenômenos humanos que podem ser estudados por uma perspectiva também humana na escola pública" (COSTA, 2015, p. 52).

Para a isso, o estudo sobre religiões deve se apoiar na sua área de referência, a CR, utilizando suas metodologias próprias, elaboradas desde sua fundação (COSTA, STERN, 2017), a partir de dois princípios básicos: a interdisciplinaridade e o estudo não normativo das religiões (COSTA, 2015).

Considerando a estrutura interna da CR, Costa (2015, p. 54) organizou sua proposta em três eixos didáticos: 1) Religiões comparadas (Ciência da Religião Sistemática); 2) Estudo empírico das religiões (Ciência da Religião empírica); 3) Conflitos e diálogo inter-religioso (Ciência da Religião Aplicada), sendo que o último vem ganhando destaque como outro desdobramento interno da CR com uma abordagem mais prática e aplicada da mesma, ou seja, dos seus resultados obtidos nas pesquisas.

Nesse primeiro momento ainda, a palestra Metodologias desenvolvidas pela genealogia intelectual da Ciência da Religião, texto também publicado por Costa em coautoria com Stern (2017), permitiu o conhecimento de várias metodologias utilizadas pela CR desde sua fundação, com destaque para "(1) métodos empíricos, (2) métodos comparativos, (3) métodos classificatórios, e um último grupo que chamamos de (4) atitude metodológica frente ao objeto" (COSTA, STERN, 2017, p. 72).

No segundo momento podemos destacar a palestra Ciência da religião e ensino religioso na BNCC: ciência da religião e educação em diálogo, com o professor Sérgio Junqueira, presidente do Instituto de Pesquisa e Formação de Educação e Religião (IPFER), que acumula uma vasta experiência na pedagogia do ER.

No terceiro momento, tivemos uma mesa com representantes de quatro Estados da Região Norte que pesquisam ou atuam nas secretarias estaduais e municipais de educação ou ainda como presidente das Associações semelhantes 
Religare, ISSN: 19826605, v.15, n.1, agosto de 2018, p.97-126.

à ACREPA, a exemplo do Amazonas (ACREPERAM - Associação dos Cientistas da Religião e dos Professores de Ensino Religioso do Amazonas) e Amapá (APERAP - Associação dos Professores de Ensino Religioso do Amapá).

Entre os pesquisadores estavam representantes da Universidade Estadual do Amazonas (UEA), Universidade Federal do Acre (UFAC) e Universidade Federal do Amapá (UNIFAP).

A mesa versou sobre $O$ ensino religioso na Região Norte, onde cada representante apresentou a situação do ER em seu Estado, destacando os avanços e desafios, assim como a grande necessidade de se investir na formação inicial com a abertura dos cursos de graduação em CR na Região.

O último momento, realizado nos dois dias do evento, era destinado como Espaço de discussão curricular, dividido em quatro partes: 1) educação infantil; 2) ensino fundamental - anos iniciais; 3) ensino fundamental - anos finais e 4) ensino médio.

Esse momento serviu para que todos os presentes tivessem acesso e pudesse contribuir com a nossa proposta da melhor forma possível.

Mesmo tendo sido iniciado em 2011 as discussões curriculares pela ACREPA, até então uma das bases de referência para isso era os PCNER (FONAPER, 2009), não indo muito, além disso.

Em 2012, durante a primeira elaboração oficial da rede estadual, trabalhamos com o conjunto de cadernos da Secretaria de Educação Básica (SEB), produzidos pelo próprio MEC em 2007.

Os cadernos serviram de base para as discussão e organização dos currículos produzidos pela SEDUC/PA até a sua última versão com a BNCC, inclusive o currículo proposto para o ER.

Os cadernos trouxeram temas de discussão teórica importantes para essa elaboração, distribuídos em cinco cadernos assim intitulados: Indagações sobre o currículo e como subtemas: currículo e desenvolvimento humano (LIMA, 2007); educandos e educadores: seus direitos e o currículo (GONZÁLES ARROYO, 
Religare, ISSN: 19826605, v.15, n.1, agosto de 2018, p.97-126.

2007); currículo, conhecimento e cultura (MOREIRA, CANDAU, 2007); diversidade e currículo (GOMES, 2007) e currículo e avaliação (FERNANDES, FREITAS, 2007).

Além desses cadernos que trazem textos de vários estudiosos do currículo, utilizamos Silva (2017); Moreira e Silva et al. (2011), Gonzáles Arroyo (2011); Lopes e Macedo (2011); Lopes e Macedo et al. (2015).

Ambos os autores destacam a centralidade que o currículo ocupa na prática educativa e como este está sob um campo de influências e negociações permanente, pois esse documento aponta ou indica alguma coisa, um lugar a se chegar, ou seja, um produto, um resultado.

Dessa forma,

[...] não podemos mais olhar o currículo com a mesma inocência de antes. $\mathrm{O}$ currículo tem significados que vão além daqueles aos quais as teorias tradicionais nos confinaram. O currículo é lugar, espaço, território. O currículo é relação de poder. O currículo é trajetória, viagem, percurso. O currículo é autobiografia, nossa vida, curriculum vitae: no currículo se forja nossa identidade. O currículo é texto, discurso, documento. O currículo é documento de identidade (SILVA, 2017, p. 150).

Nesses termos, os referidos autores permitiram o enriquecimento significativo para pensar um currículo escolarizado, ou seja, científico e laico para o ER.

Abaixo, segue um pouco da estrutura e evolução curricular adaptada por mim até a última versão que considera as orientações da última versão da BNCC.

O quadro 01 apresenta de forma breve a primeira estrutura de planejamento curricular organizada pela ACREPA. Essa estrutura priorizou as orientações do PCNER organizados pelo FONAPER desde 1996, conforme podemos observar abaixo:

Quadro 01: Planejamento curricular do ensino religioso para educação básica no Pará (2011).

\begin{tabular}{|c|l|lr|lr|}
\hline $\begin{array}{c}\text { Eixo temático ou } \\
\text { conteúdo } \\
\text { estruturante }\end{array}$ & Conteúdos básicos & Tratamento didático & $\begin{array}{l}\text { Encaminhamento para a } \\
\text { avaliação da aprendizagem }\end{array}$ \\
\hline $\begin{array}{l}\text { Baseado nos cinco } \\
\text { eixos temáticos } \\
\text { propostos pelo }\end{array}$ & $\begin{array}{l}\text { Recortes temáticos } \\
\text { dos eixos para cada } \\
\text { ano/ciclo/série da da }\end{array}$ & $\begin{array}{l}\text { Orientações } \\
\text { mediações } \\
\text { pedagógicas }\end{array}$ & dos & $\begin{array}{l}\text { Orientações } \\
\text { avaliação }\end{array}$ & para \\
aprendizagem em cada \\
\hline
\end{tabular}


Religare, ISSN: 19826605, v.15, n.1, agosto de 2018, p.97-126.

\begin{tabular}{|l|l|l|l|}
\hline FONAPER. & Educação Básica. & $\begin{array}{l}\text { conteúdos básicos } \\
\text { para a prática do do } \\
\text { professor. }\end{array}$ & $\begin{array}{l}\text { ano/ciclo/série a partir } \\
\text { dos conteúdos básicos. }\end{array}$ \\
\hline
\end{tabular}

Fonte: organizado pelos autores.

Já o quadro 02 inaugura as discussões oficiais com a SEDUC/PA iniciadas em 2012. Apesar de a estrutura curricular ser diferente, as referências aplicadas ao ER partem ainda dos PCNER, como segue abaixo:

Quadro 02: Estrutura curricular da rede estadual de ensino do Pará (2012).

\begin{tabular}{|c|c|c|c|c|c|c|}
\hline Etapa & $\begin{array}{c}\text { Ementa das } \\
\text { ciências } \\
\text { humanas }\end{array}$ & $\begin{array}{c}\text { Ementa da } \\
\text { disciplina }\end{array}$ & $\begin{array}{c}\text { Eixos } \\
\text { temáticos }\end{array}$ & Conteúdos & Competências & Habilidades \\
\hline $\begin{array}{l}\text { Ensino } \\
\text { Fundam } \\
\text { ental } \\
\left(1^{o} \text { ao } 9^{o}\right. \\
\text { anos })\end{array}$ & $\begin{array}{l}\text { Aspectos } \\
\text { comuns aos } \\
\text { componentes } \\
\text { curriculares } \\
\text { da grande } \\
\text { área. }\end{array}$ & $\begin{array}{l}\text { Aspectos } \\
\text { específicos } \\
\text { ao } \\
\text { component } \\
\text { e } \\
\text { curricular. }\end{array}$ & $\begin{array}{l}\text { Baseados } \\
\text { na proposta } \\
\text { dos } \\
\text { parâmetros } \\
\text { do ER do } \\
\text { FONAPER. }\end{array}$ & $\begin{array}{l}\text { Retirados a } \\
\text { partir dos } \\
\text { eixos dos } \\
\text { parâmetros } \\
\text { do } \\
\text { FONAPER. }\end{array}$ & $\begin{array}{l}\text { Relacionada } \\
\text { à } \\
\text { apropriação } \\
\text { do } \\
\text { conheciment } \\
\text { o } \\
\text { apresentado. }\end{array}$ & $\begin{array}{l}\text { Aplicação } \\
\text { prática do } \\
\text { conhecimen } \\
\text { to } \\
\text { apresentad } \\
\text { o. }\end{array}$ \\
\hline
\end{tabular}

Fonte: organizado pelos autores.

O quadro 03, apesar de apresentar uma discussão mais aprofundada, representando uma evolução nas propostas curriculares anteriores, em relação ao ER isso pouco aconteceu. Em meio às discussões, seminários e publicação de três versões da BNCC, ainda nossa proposta estava baseada na Fenomenologia da experiência religiosa, fortemente ligada à proposta do FONAPER, mas esse aspecto era um dos que permeavam nosso currículo até 2017 e não invalidava a abordagem da diversidade cultural religiosa nas escolas paraenses que acontecia normalmente.

Quadro 03: Estrutura curricular da rede estadual de ensino do Pará (2013-2017). Eixos

1. O espaço/tempo e suas transformações; 2. Linguagens e suas formas comunicativas; 3. Valores para a vida social;4. Cultura e identidade.

$$
\text { Ciclos da Aprendizagem }
$$

Ciclo I: ( $1^{\mathrm{o}}$ ao $3^{\mathrm{o}}$ anos); ciclo II: ( $4^{\mathrm{o}}$ ao $\left.5^{\mathrm{o}}\right)$; ciclo III: $\left(6^{\underline{\mathrm{o}}}\right.$ ao $\left.7^{\mathrm{o}}\right)$; ciclo IV: $\left(8^{\mathrm{o}}\right.$ ao $\left.9^{\mathrm{o}}\right)$.

\section{Subeixos}

Recortes do conhecimento do componente curricular adaptado em cada um dos eixos e ciclos da aprendizagem.

Fonte: organizado pelos autores.
Objetivos de aprendizagem (para os alunos)

Promover condições favoráveis de ensinoaprendizado aos conhecimentos trabalhados com os alunos. 
Religare, ISSN: 19826605, v.15, n.1, agosto de 2018, p.97-126.

O quadro abaixo destaca brevemente três elementos básicos que organizam o ER na BNCC, homologada em dezembro de 2017. O currículo do ER está organizado nesse documento em quatro unidades temáticas, onde cada uma dessas unidades indica objetos de conhecimento e habilidades a serem alcançadas durante a prática pedagógica desse docente de forma não confessional, ou seja, nesse processo a CR é fundamental para esse fim.

Quadro 04: Proposta do ER aprovada na BNCC ${ }^{6}$ (2017-)

\begin{tabular}{|c|c|c|}
\hline $\begin{array}{l}\text { Unidade } \\
\text { Temática }\end{array}$ & Objetos do Conhecimento & Habilidades \\
\hline $\begin{array}{l}1 . \\
\text { Identidades e } \\
\text { alteridades } \\
\left(1^{\circ}, \quad 2^{\circ}, \quad 3^{\circ}\right. \\
\text { anos) }\end{array}$ & $\begin{array}{l}\text { Reconhecer, valorizar e acolher o caráter singular e diverso do } \\
\text { ser humano, por meio da identificação e do respeito às } \\
\text { semelhanças e diferenças entre o eu (subjetividade) e os outros } \\
\text { (alteridades), da compreensão dos símbolos e significados e da } \\
\text { relação entre imanência e transcendência. }\end{array}$ & $\begin{array}{l}\mathrm{Na} \text { BNCC é } \\
\text { definida como } \\
\text { práticas, } \\
\text { cognitivas e } \\
\text { socioemocionais }\end{array}$ \\
\hline $\begin{array}{l}\text { Manifestaçõe } \\
\text { S religiosas } \\
\left(1^{\mathrm{o}}, 2^{\circ}, 3^{\circ}, 4^{\underline{\mathrm{o}}},\right. \\
\left.7^{\mathrm{o}} \text { anos }\right)\end{array}$ & $\begin{array}{l}\text { Proporcionar o conhecimento, a valorização e o respeito às } \\
\text { distintas experiências e manifestações religiosas, e a } \\
\text { compreensão das relações estabelecidas entre as lideranças e } \\
\text { denominações religiosas e as distintas esferas sociais. }\end{array}$ & $\begin{array}{l}\text { que resultam } \\
\text { em atitudes e } \\
\text { valores para } \\
\text { resolver } \\
\text { demandas }\end{array}$ \\
\hline $\begin{array}{l}\text { Crenças } \\
\text { religiosas e } \\
\text { filosofias de } \\
\text { vida }\left(4^{\circ}, 5^{\circ} \text {, }\right. \\
6^{\circ}, 7^{\circ}, 8^{\circ}, 9^{\circ} \\
\text { anos) }\end{array}$ & $\begin{array}{l}\text { Tratar aspectos } \begin{array}{c}\text { estruturantes } \\
\text { tradições/movimentos religiosos e filosofias de vida, }\end{array} \\
\text { particularmente sobre mitos, ideia(s) de divindade(s), crenças e } \\
\text { doutrinas religiosas, tradições orais e escritas, ideias de } \\
\text { imortalidade, princípios e valores éticos. }\end{array}$ & $\begin{array}{lr}\text { complexas } & \text { da } \\
\text { vida cotidiana, } \\
\text { do } & \text { pleno } \\
\text { exercício } & \text { da } \\
\text { cidadania } & \text { e do } \\
\text { mundo } & \text { do } \\
\text { trabalho. } & \end{array}$ \\
\hline
\end{tabular}

Fonte: organizado pelos autores, a partir da BNCC (BRASIL, 2017).

O quadro 05 é um breve resumo da fusão entre a proposta da BNCC e a da SEDUC/PA, ressaltando que cada Secretaria de Educação tem autonomia para organizar seus currículos de acordo com suas especificidades e demandas pedagógicas. Nesse aspecto, a SEDUC/PA organizou o seu currículo em anos de

\footnotetext{
${ }^{6} \mathrm{O}$ retorno do ER a $4^{\mathrm{a}}$ versão da $\mathrm{BNCC}$, retirado da $3^{3}$, está envolto em algumas questões ainda por ser resolverem. 1. Segundo a Portaria no 1.570, de 20/12/2017, em seu Artigo $2^{\circ}$ destaca que "Após a publicação do Acórdão do Supremo Tribunal Federal no julgamento da Ação Direta de Inconstitucionalidade no ${ }^{4}$ 439, o Ministério da Educação poderá solicitar ao Conselho Nacional de Educação reavaliação do disposto para o ensino religioso na BNCC". 2. Segundo a Resolução $\mathrm{CNE} / \mathrm{CP}$ no 2, de 22/12/2017, em seu Art. 23 afirma que “O CNE, mediante proposta de comissão específica, deliberará se o ensino religioso terá tratamento como área do conhecimento ou como componente curricular da área de Ciências Humanas, no Ensino Fundamental". Esse aspecto é reforça do Parecer CNE/CP no 15, de 15/12/207 e aprovado pela referida Portaria.
} 
Religare, ISSN: 19826605, v.15, n.1, agosto de 2018, p.97-126.

aprendizagem, salvo o $1^{o}$ e $2^{o}$ anos, eixos, subeixos, objetivos da aprendizagem e habilidades.

Quadro 05: Estrutura curricular da rede estadual de ensino do Pará a partir da BNCC (2018-). Ciclos da Aprendizagem

Ciclo I: ( $1^{\circ}$ ao $3^{\circ}$ anos); ciclo II: ( $4^{\circ}$ ao $\left.5^{\circ}\right)$; ciclo III: ( $6^{\circ}$ ao $\left.7^{\circ}\right)$; ciclo IV: $\left(8^{\circ}\right.$ ao $\left.9^{\circ}\right)$. Eixos

1. O espaço/tempo e suas transformações; 2. Linguagens e suas formas comunicativas; 3. Valores para a vida social; 4 . Cultura e identidade.

\begin{tabular}{|c|c|c|}
\hline Subeixos & $\begin{array}{l}\text { Objetivos de } \\
\text { aprendizagem }\end{array}$ & Habilidades \\
\hline $\begin{array}{l}\text { Na BNCC refere-se aos objetos } \\
\text { do conhecimento. Na estrutura } \\
\text { da rede estadual refere-se aos } \\
\text { recortes do conhecimento } \\
\text { trabalhado no componente } \\
\text { curricular e articulado com } \\
\text { cada eixo estruturante. }\end{array}$ & $\begin{array}{lr}\text { Promover } & \text { condições } \\
\text { favoráveis de ensino- } \\
\text { aprendizado para que } \\
\text { os conhecimentos } \\
\text { estudados r sejam } \\
\text { alcançados. }\end{array}$ & $\begin{array}{l}\text { Atitudes e valores e, sobretudo, do } \\
\text { que devem "saber fazer" } \\
\text { (considerando a mobilização desses } \\
\text { conhecimentos, habilidades, } \\
\text { atitudes e valores para resolver } \\
\text { demandas complexas da vida } \\
\text { cotidiana, do pleno exercício da } \\
\text { cidadania e do mundo do trabalho). }\end{array}$ \\
\hline
\end{tabular}

Fonte: organizado pelos autores.

O quadro 06 apresenta a proposta de currículo do ER para a rede estadual de ensino do Pará, homologado em dezembro de 2018, pelo Conselho Estadual de Educação do Pará (CEE/PA), mas que ainda não se encontra na sua versão definitiva.

Durante o ano de 2018, vários ajustes foram realizados, como a organização em ciclos e a sugestão de deixar um anexo organizado em anos, com exceção do $1^{\circ}$ e $2^{\circ}$ ano que no anexo ficaria em ciclo; a inclusão dos códigos das habilidades da BNCC nas habilidades do documento e a correspondência entre subeixos, objetivos de aprendizagem e habilidades, aproximando-se de certa forma da organização da BNCC apresentados em unidades temáticas, objetos de conhecimento e habilidades.

Apesar das dificuldades, entre os Cientistas da Religião, ou seja, entre os professores licenciados nesta área, é notória a compreensão de que o ER é um componente curricular como os demais e que sua área de conhecimento é a Ciência da Religião e que a mesma pertence a Grande Área das Ciências Humanas como prevê o próprio documento da área na Coordenação de Aperfeiçoamento de Pessoal de Nível Superior (CAPES) (STERN, 2018). 
Religare, ISSN: 19826605, v.15, n.1, agosto de 2018, p.97-126.

A indicação do ER como área de conhecimento à parte das demais (BRASIL, 1998) permitiu que esse equívoco fosse adiante e se reproduzisse nos documentos legais que se seguiram (BRASIL, 2010a; 2010b), assim como na própria BNCC (BRASIL, 2017a; 2017b).

A trajetória da CR no Brasil inicia-se em 1969, com a criação do Departamento de Ciências das Religiões, na Universidade de Juiz de Fora (UFJF) e o primeiro e único vestibular para o curso de graduação na modalidade bacharelado de Ciência das Religiões em 1976 (TEIXEIRA, 2012).

Os cursos de graduação, agora na modalidade licenciatura, iniciaram em 1996 em Santa Catarina e, em 2000 no Pará, espalhando-se para quase todas as regiões do país (SANTOS, 2014).

A criação dos Programas de Pós-graduação em CR inicia em 1978, sendo o primeiro deles na Pontifícia Universidade Católica de São Paulo (PUCSP), mesmo que a CR tenha coexistido com a Teologia como subcomissão da área de avaliação da Filosofia, ambas dentro da Grande Área de Ciências Humanas, algo que só vai mudar com a criação da área de avaliação 44 de Ciência da Religião e Teologia em 2016 (STERN, 2018).

A área 44, só para reforçar, é integrante das Ciências Humanas, por isso achamos que o ER não pode ser um componente deslocado ou isolado no tratamento político-legal e pedagógico-didático, como ainda constam nas Resoluções educacionais.

O exercício aqui empreendido vai nesse sentido, de mostrar porque ainda estamos e devemos permanecer no currículo da escola. A CR é uma área de conhecimento autônoma como quaisquer outras das Ciências Humanas, não cabendo à mesma nenhuma exceção epistemológica, muito menos pedagógica quando se trata da sua aplicação nas escolas públicas.

Tratar o ER com exceção científica ou mesmo como uma área de conhecimento ou componente curricular a ser definido, demonstra que as lutas e negociações no campo do currículo ainda estão com toda força. 
Religare, ISSN: 19826605, v.15, n.1, agosto de 2018, p.97-126.

O embate entre aqueles que são contra o ER confessional e/ou interconfessional são compreensíveis, mas ser contra o ER com base na CR não se justifica simplesmente pelo fato de seu objeto de estudo ser a religião, que não se restringe apenas a CR, quando que nesta área esse objeto alcança níveis de análise bem mais abrangentes devido a sua estrutura interna organizada em dois ramos distintos (empírico/histórico e comparativo/sistemático), porém inter-relacionados.

Dessa forma, antes mesmo de qualquer avaliação prévia é importante conhecer essa disciplina autônoma, assim como a sua aplicação apresentada no quadro 06, como um exercício que estará sempre em efetiva construção e aprimoramento no Brasil.

Quadro 06: Proposta de currículo do ER da SEDUC/PA a partir da BNCC ${ }^{7}$. COMPONENTE CURRICULAR: ENSINO RELIGIOSO

\begin{tabular}{|c|c|}
\hline & ENSINO RELIGIOSO \\
\hline CICLO 1: 1 & $2^{\circ}$ E $3^{\circ}$ ANO DO ENSINO FUNDAMENTAL \\
\hline EIXO 1:O ES & PAÇO/TEMPO E SUAS TRANSFORMAÇÕES \\
\hline $\begin{array}{l}\text { Subeixos: } 1 \text {. Representações } \mathrm{r} \\
\text { Diversidade religiosa. }\end{array}$ & ligiosas; 2. Religiões locais; 3. Espaços seculares e religiosos; 4. \\
\hline Objetivos de aprendizagem & HABILIDADES \\
\hline $\begin{array}{l}1.1 \text { Identificar as } \begin{array}{r}\text { ideias e } \\
\text { representações } \\
\text { religiões. }\end{array} \\
\text { sobre }\end{array}$ & $\begin{array}{l}\text { (EF03ER03) Identificar e respeitar práticas celebrativas } \\
\text { (cerimônias, orações, festividades, peregrinações, entre outras) } \\
\text { de diferentes tradições religiosas. } \\
\text { (EF01ER01PA) Perceber na sua convivência a existência das } \\
\text { religiões }\end{array}$ \\
\hline $\begin{array}{l}\text { 2.1 Conhecer as religiões } \\
\text { presentes no seu entorno. }\end{array}$ & $\begin{array}{l}\text { (EF02ER01PA) Identificar com respeito às religiões presentes no } \\
\text { seu bairro. } \\
\text { (EF03ER02) Caracterizar os espaços e territórios religiosos como } \\
\text { locais de realização das práticas celebrativas. }\end{array}$ \\
\hline $\begin{array}{l}\text { 3.1 Mostrar os diferentes } \\
\text { espaços seculares e religiosos } \\
\text { paraenses. }\end{array}$ & $\begin{array}{l}\text { (EF03ER01) Identificar e respeitar os diferentes espaços e } \\
\text { territórios religiosos de diferentes tradições e movimentos } \\
\text { religiosos. } \\
\text { (EF03ER01PA) Diferenciar e respeitar os lugares religiosos e } \\
\text { não religiosos. }\end{array}$ \\
\hline $\begin{array}{l}4.1 \text { Conhecer as religiões } \\
\text { presentes na sociedade } \\
\text { brasileira. }\end{array}$ & $\begin{array}{l}\text { (EF03ER04) Caracterizar as práticas celebrativas como parte } \\
\text { integrante do conjunto das manifestações religiosas de } \\
\text { diferentes culturas e sociedades. } \\
\text { (EF02ER02PA) Identificar a diversidade religiosa paraense. }\end{array}$ \\
\hline
\end{tabular}

${ }^{7}$ Currículo elaborado por vários professores de Ensino Religioso das redes de ensino no Pará. Todos graduados em Ciência da Religião pela Universidade do Estado do Pará (UEPA). Nesse percurso, a ACREPA tem viabilizado vários espaços de discussões, inclusive curriculares, o que vem permitindo a consolidação desse profissional no Estado do Pará. Esta proposta curricular ainda em fase de finalização consta no documento apresentando ao CEE/PA em 08/11/2018. 
Religare, ISSN: 19826605, v.15, n.1, agosto de 2018, p.97-126.

\section{ENSINO RELIGIOSO}

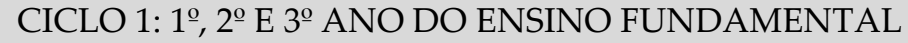

EIXO 2: LINGUAGENS E SUAS FORMAS COMUNICATIVAS

Subeixos: 1. Elementos culturais e religiosos; 2. Narrativas e histórias religiosas; 3. Práticas celebrativas; 4 . Símbolos seculares e religiosos.

Objetivos de aprendizagem $\quad$ HABILIDADES

1.1 Conhecer os elementos culturais que se relacionam com as religiões, destacando o contexto paraense.

\subsection{Conhecer e comparar} diferentes temas nas narrativas e histórias religiosas.

3.1 Conhecer e diferenciar as práticas celebrativas seculares e religiosas.

4.1 Conhecer os símbolos religiosos e seculares, assim como seus significados.

\section{das seculares. \\ CICLO 1: $1^{\circ}, 2^{\circ}$ E $3^{\circ}$ ANO DO ENSINO FUNDAMENTAL EIXO 3: VALORES À VIDA SOCIAL}

Subeixos: 1. Conhecendo-se; Os outros e a sua importância; Direitos e cuidados de si e dos outros; 4 . Convivência em respeito: liberdade e tolerância religiosa.

\section{\begin{tabular}{|l|l} 
Objetivos de aprendizagem & HABILIDADES
\end{tabular}}

1.1 Favorecer o (EF02ER03) Identificar as diferentes formas de registro das autoconhecimento como memórias pessoais, familiares e escolares (fotos, músicas, identidade pessoal narrativas, álbuns...).

construída no seu convívio (EF01ER03PA) Expor com segurança e autoestima a formação familiar e sociocultural. da sua identidade.

2.1 Destacar a importância da (EF01ER01) Identificar e acolher as semelhanças e diferenças convivência pacífica e entre o eu, o outro e o nós.

respeitosa entre diferentes (EF02ER04PA) Demonstrar respeito diante das diferenças pessoas e grupos.

humanas e socioculturais.

3.1 Orientar com base nos direitos sociais e humanos, sem quaisquer distinções.

(EF01ER05) Identificar e acolher sentimentos, lembranças, memórias e saberes de cada um.

(EF03ER03PA) Reconhecer a importância do respeito diante das regras familiares, religiosas e sociais.

4.1. Incentivar o respeito às (EF01ER06) Identificar as diferentes formas pelas quais as diferenças religiosas e pessoas manifestam sentimentos, ideias, memórias, gostos e humanas, considerando os crenças em diferentes espaços.

princípios legais.

(EF02ER05PA) Perceber e reconhecer os direitos humanos, com destaque para a liberdade de crença e a tolerância religiosa. 
Subeixos: 1. Manifestações religiosas; 2.Conhecendo religiões; 3. Diversidade religiosa; 4. Religiões no Brasil.

\begin{tabular}{|l|}
\hline \multicolumn{3}{|c|}{ Objetivos de aprendizagem } \\
\hline 1.1 Mostrar as diferentes \\
manifestações religiosas na \\
Amazônia.
\end{tabular}

2.1 Conhecer alguns aspectos que caracterizam as religiões na Amazônia.

3.1 Conhecer a diversidade religiosa e secular paraense.

$\begin{aligned} & 4.1 \quad \text { Mostrar as } \\ & \text { presentes religiões } \\ & \text { brasileira. }\end{aligned}$

\section{HABILIDADES}

(EF01ER04PA) Identificar e respeitar as religiões presentes ao seu redor.

(EF02ER06) Exemplificar alimentos considerados sagrados por diferentes culturas, tradições e expressões religiosas.

(EF02ER06PA) Identificar e reconhecer elementos que caracterizam as religiões.

(EF03ER05) Reconhecer as indumentárias (roupas, acessórios, símbolos, pinturas corporais) utilizadas em diferentes manifestações e tradições religiosas.

(EF02ER07PA) Identificar e respeitar as diferentes manifestações, religiosas e não religiosas.

(EF03ER06) Caracterizar as indumentárias como elementos integrantes das identidades religiosas.

(EF02ER07) Identificar significados atribuídos a alimentos em diferentes manifestações e tradições religiosas

(EF03ER04PA) Identificar as religiões presentes no Brasil, destacando o contexto regional e local.

ENSINO RELIGIOSO

CICLO 2: $4^{\circ}$ E $5^{\circ}$ ANO DO ENSINO FUNDAMENTAL

EIXO 1: O ESPAÇO/TEMPO E SUAS TRANSFORMAÇÕES

Subeixos: 1. As primeiras religiões; 2. Religiões e sociedade; 3. Religiões e vida pública; 4. Interações nos espaços religiosos.

Objetivos de aprendizagem

1.1 Conhecer a historia do surgimento das primeiras religiões.

2.1 Mostrar a presença e
influência das religiões na
sociedade.

3.1 Estudar as relações e o papel das religiões na vida pública.

4.1 Conhecer os espaços religiosos da sua região.

\section{HABILIDADES}

(EF04ER04) Identificar as diversas formas de expressão da espiritualidade (orações, cultos, gestos, cantos, dança, meditação) nas diferentes tradições religiosas.

(EF05ER01PA) Identificar e localizar o espaço/tempo das primeiras religiões

(EF05ER01) Identificar e respeitar acontecimentos sagrados de diferentes culturas e tradições religiosas como recurso para preservar a memória

(EF04ER01PA) Identificar como a presença das religiões é percebida nas ações das pessoas.

(EF04ER02PA) Identificar e reconhecer a influência e os limites das religiões no dia a dia.

(EF05ER03) Reconhecer funções e mensagens religiosas contidas nos mitos de criação (concepções de mundo, natureza, ser humano, divindades, vida e morte).

(EF04ER05) Identificar representações religiosas em diferentes expressões artísticas (pinturas, arquitetura, esculturas, ícones, símbolos, imagens), reconhecendo-as como parte da identidade de diferentes culturas e tradições religiosas.

(EF05ER02PA) Identificar nas paisagens urbanas e rurais santuários, templos e outros espaços religiosos.

ENSINO RELIGIOSO

CICLO 2: $4^{\circ}$ E $5^{\circ}$ ANOS DO ENSINO FUNDAMENTAL EIXO 2: LINGUAGENS E SUAS FORMAS COMUNICATIVAS 
Subeixos: 1. As origens e o começo; 2. Ritos religiosos e seculares; 3. Textos escritos e orais das religiões; 4 . Divindades e seres sobre-humanos.

Objetivos de aprendizagem

1.1 Conhecer as narrativas religiosas e seculares sobre o surgimento da vida.

2.1 Mostrar a função e distinção entre ritos religiosos e seculares.

\section{HABILIDADES}

(EF05ER02) Identificar narrativas de criação em diferentes culturas e tradições religiosas.

(EF04ER03PA) Respeitar os relatos religiosos e seculares sobre as origens humanas e do universo

(EF04ER01) Identificar ritos presentes no cotidiano pessoal, familiar, escolar e comunitário.

(EF04ER02) Identificar ritos e suas funções em diferentes manifestações e tradições religiosas.

(EF04ER03) Caracterizar ritos de iniciação e de passagem em diversos grupos religiosos (nascimento, casamento e morte)

(EF05ER03PA) Identificar e respeitar os ritos religiosos e não religiosos.

3.1 Conhecer e comparar os textos escritos e orais das religiões.

(EF04ER04PA) Identificar a função dos textos escritos e orais das religiões.

(EF05ER04) Reconhecer a importância da tradição oral para preservar memórias e acontecimentos religiosos.

4.1 Conhecer as ideias sobre divindades e seres sobrehumanos das religiões.

(EF04ER06) Identificar nomes, significados e representações de divindades nos contextos familiar e comunitário.

(EF05ER04PA) Identificar e perceber as representações de seres sobre-humanos como patrimônio histórico-cultural material e imaterial na cultura regional e local.

ENSINO RELIGIOSO

CICLO 2: $4^{\circ}$ E $5^{\circ}$ ANOS DO ENSINO FUNDAMENTAL

EIXO 3: VALORES À VIDA SOCIAL

Subeixos: 1. Cuidados de si e do outro; 2. Normas e valores religiosos e seculares; 3. Direitos humanos; 4 . Diálogo e respeito entre religiões.

\begin{tabular}{|c|c|}
\hline Objetivos de aprendizagem & HABILIDADES \\
\hline $\begin{array}{l}\text { 1.1 Destacar o cuidado de si e } \\
\text { do outro na perspectiva dos } \\
\text { direitos humanos. }\end{array}$ & $\begin{array}{l}\text { (EF05ER01) Identificar e respeitar acontecimentos sagrados de } \\
\text { diferentes culturas e tradições religiosas como recurso para } \\
\text { preservar a memória. } \\
\text { (EF04ER05PA) Entender a importância da prática do respeito } \\
\text { mútuo, com base na igualdade entre pessoas. }\end{array}$ \\
\hline $\begin{array}{l}2.1 \quad \text { Conhecer normas } \\
\text { religiosas e seculares. }\end{array}$ & $\begin{array}{l}\text { (EF05ER05) Identificar elementos da tradição oral nas culturas e } \\
\text { religiosidades indígenas, afro-brasileiras, ciganas, entre outras. } \\
\text { (EF04ER06PA) Perceber como os valores religiosos e seculares } \\
\text { ajudam na organização social. }\end{array}$ \\
\hline $\begin{array}{l}3.1 \text { Conhecer princípios } \\
\text { legais sobre os direitos } \\
\text { humanos e a liberdade } \\
\text { religiosa. }\end{array}$ & $\begin{array}{l}\text { (EF04ER07) Reconhecer e respeitar as ideias de divindades de } \\
\text { diferentes manifestações e tradições religiosas. } \\
\text { (EF05ER06PA) Reconhecer e respeitar o direito de ter ou não } \\
\text { uma crença religiosa. }\end{array}$ \\
\hline $\begin{array}{l}\text { 4.1 Mostrar a importância do } \\
\text { diálogo entre as religiões e } \\
\text { setores seculares. }\end{array}$ & $\begin{array}{l}\text { (EF04ER04) Identificar as diversas formas de expressão da } \\
\text { espiritualidade (orações, cultos, gestos, cantos, dança, } \\
\text { meditação) nas diferentes tradições religiosas. } \\
\text { (EF05ER07PA) Reconhecer a importância do diálogo } \\
\text { intercultural. }\end{array}$ \\
\hline \multicolumn{2}{|r|}{ ENSINO RELIGIOSO } \\
\hline \multicolumn{2}{|c|}{ CICLO 2: $4^{\circ}$ E $5^{\circ}$ ANO DO ENSINO FUNDAMENTAL } \\
\hline & \\
\hline
\end{tabular}


Subeixos: 1. Matrizes cultural-religiosas do Brasil; 2. Religiões e manifestações artísticoculturais; 3. Manifestações da religiosidade popular; 4. Novas religiosidades e espiritualidades.

Objetivos de aprendizagem

1.1 Mostrar as matrizes cultural-religiosas brasileiras.

2.1 Conhecer os aspectos religiosos presentes nas manifestações artísticoculturais regionais e locais.

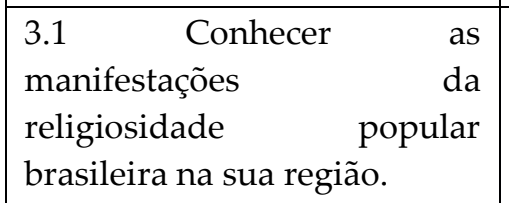

\begin{tabular}{|lrr}
\hline 4.1 & Contextualizar & o \\
surgimento & de & novas \\
religiosidades & & e \\
espiritualidades & no & país, \\
destacando & o & contexto \\
paraense. & &
\end{tabular}

\section{ENSINO RELIGIOSO$$
\text { CICLO 3: } 6^{\circ} \text { E 7을 ANOS DO ENSINO FUNDAMENTAL }
$$$$
\text { EIXO 1: O ESPAÇO/TEMPO E SUAS TRANSFORMAÇÕES }
$$

Subeixos: 1. O Surgimento das religiões; 2. Classificação das religiões; 3. Religiões do Brasil; 4. Espaços religiosos e seculares.

\begin{tabular}{l|l} 
Objetivos de aprendizagem & HABILIDADES
\end{tabular}

1.1 Estudar o contexto (EF06ER01) Reconhecer o papel da tradição escrita na espaço-temporal de preservação de memórias, acontecimentos e ensinamentos surgimento das religiões. $\quad$ religiosos.

(EF06ER01PA) Compreender como as religiões surgiram.

1.2 Estudar a classificação (EF06ER06) Reconhecer a importância dos mitos, ritos, das religiões.

1.3 Mostrar o cenário cultural-religioso brasileiro.

1.4 Conhecer os diferentes espaços religiosos e seculares na paisagem brasileira. símbolos e textos na estruturação das diferentes crenças, tradições e movimentos religiosos.

(EF06ER02PA) Entender os tipos de religiões.

(EF07ER01PA) Identificar as religiões presentes no território brasileiro, destacando o contexto paraense.

(EF07ER01) Reconhecer e respeitar as práticas de comunicação com as divindades em distintas manifestações e tradições religiosas.

(EF07ER02PA) Identificar e respeitar os locais, religiosos e seculares regionais e locais.

(EF06ER07) Exemplificar a relação entre mito, rito e símbolo nas práticas celebrativas de diferentes tradições religiosas. ENSINO RELIGIOSO CICLO 3: $6^{\circ}$ E 7을 ANO DO ENSINO FUNDAMENTAL EIXO 2: LINGUAGENS E SUAS FORMAS COMUNICATIVAS

Subeixos: 1. As origens: narrativas religiosas e seculares; 2. Caracterização de divindades e seres sobre-humanos; 3 . Aspectos dos ritos; 4 . Símbolos e signos religiosos e seculares. 
Religare, ISSN: 19826605, v.15, n.1, agosto de 2018, p.97-126.

\begin{tabular}{|c|c|}
\hline Objetivos de aprendizagem & HABILIDADES \\
\hline 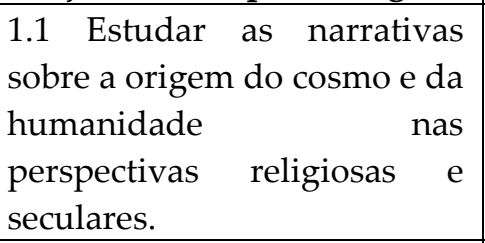 & $\begin{array}{l}\text { (EF06ER04) Reconhecer que os textos escritos são utilizados } \\
\text { pelas tradições religiosas de maneiras diversas. } \\
\text { (EF06ER03PA) Reconhecer os relatos de criação do universo e } \\
\text { das pessoas com bases religiosas e seculares. }\end{array}$ \\
\hline $\begin{array}{l}2.1 \text { Estudar as características } \\
\text { atribuídas às divindades e } \\
\text { seres sobre-humanos nas } \\
\text { religiões e espiritualidades. }\end{array}$ & $\begin{array}{l}\text { (EF07ER01) Reconhecer e respeitar as práticas de comunicação } \\
\text { com as divindades em distintas manifestações e tradições } \\
\text { religiosas. } \\
\text { (EF07ER03PA) Identificar e respeitar as ideias atribuídas aos } \\
\text { seres sobre-humanos nas religiões e espiritualidades locais. }\end{array}$ \\
\hline $\begin{array}{l}\text { 3.1 Estudar os aspectos que } \\
\text { caracterizam e diferenciam } \\
\text { os ritos nas religiões e } \\
\text { espiritualidades. }\end{array}$ & $\begin{array}{l}\text { (EF06ER07) Exemplificar a relação entre mito, rito e símbolo nas } \\
\text { práticas celebrativas de diferentes tradições religiosas. } \\
\text { (EF07ER04PA) Compreender e respeitar os ritos que estão } \\
\text { presentes nas religiões e espiritualidades locais. }\end{array}$ \\
\hline $\begin{array}{l}\text { 4.1 Conhecer os símbolos e } \\
\text { signos religiosos e seculares. }\end{array}$ & $\begin{array}{l}\text { (EF06ER06) Reconhecer a importância dos mitos, ritos, } \\
\text { símbolos e textos na estruturação das diferentes crenças, } \\
\text { tradições e movimentos religiosos. } \\
\text { (EF07ER05PA) Reconhecer e diferenciar os símbolos e sinais } \\
\text { que estão presentes nos objetos, imagens e figuras religiosas ou } \\
\text { não. }\end{array}$ \\
\hline \\
\hline \multicolumn{2}{|c|}{ CICLO 3: $6^{\circ}$ E $7^{\circ}$ ANO DO ENSINO FUNDAMENTAL } \\
\hline \multicolumn{2}{|r|}{ EIXO 3: VALORES À VIDA SOCIAL } \\
\hline \multicolumn{2}{|c|}{$\begin{array}{l}\text { Subeixos: } 1 \text {. Princípios e normas para a vida social; } 2 \text {. Valores éticos e estéticos; } 3 \text {. O papel das } \\
\text { instituições na formação de valores; } 4 \text {. Fundamentalismos e intolerância religiosa. }\end{array}$} \\
\hline Objetivos de aprendizagem & HABILIDADES \\
\hline $\begin{array}{l}\text { 1.1 Conhecer os princípios e } \\
\text { normas estabelecidas para a } \\
\text { vida social em sua } \\
\text { diversidade. }\end{array}$ & $\begin{array}{l}\text { (EF07ER06) Identificar princípios éticos em diferentes tradições } \\
\text { religiosas e filosofias de vida, discutindo como podem } \\
\text { influenciar condutas pessoais e práticas sociais. } \\
\text { (EF06ER05PA) Reconhecer e respeitar os princípios e normas } \\
\text { que organizam o coletivo social e aqueles compartilhados no } \\
\text { universo religioso regional e local. }\end{array}$ \\
\hline $\begin{array}{l}2.1 \text { Conhecer os valores } \\
\text { éticos e estéticos na cultura } \\
\text { brasileira. }\end{array}$ & $\begin{array}{l}\text { (EF06ER06PA) Reconhecer os significados éticos e estéticos } \\
\text { presentes na cultura religiosa local. } \\
\text { (EF07ER05) Discutir estratégias que contribuam para a } \\
\text { convivência ética e respeitosa entre as religiões. }\end{array}$ \\
\hline $\begin{array}{l}\text { 3.1 Estudar o papel histórico- } \\
\text { social das instituições e } \\
\text { outros setores na formação } \\
\text { de valores humanos. }\end{array}$ & $\begin{array}{l}\text { (EF07ER07) Identificar e discutir o papel das lideranças } \\
\text { religiosas e seculares na defesa e promoção dos direitos } \\
\text { humanos. } \\
\text { (EF07ER06PA) Perceber o desenvolvimento e função de normas } \\
\text { estabelecidas por instituições e grupos organizados. }\end{array}$ \\
\hline $\begin{array}{l}\text { 4.1 Conhecer as motivações } \\
\text { religiosas que alimentam os } \\
\text { fundamentalismos } \quad \text { e } \\
\text { fanatismos religiosos. }\end{array}$ & $\begin{array}{l}\text { (EF07ER08) Reconhecer o direito à liberdade de consciência, } \\
\text { crença ou convicção, questionando concepções e práticas sociais } \\
\text { que a violam. } \\
\text { (EF06ER07PA) Entender e combater as ideias que alimentam } \\
\text { várias formas de discriminação e preconceito, em especial, a } \\
\text { intolerância religiosa. }\end{array}$ \\
\hline \multicolumn{2}{|r|}{ ENSINO RELIGIOSO } \\
\hline \multicolumn{2}{|c|}{ CICLO 3: $6^{\circ}$ E $7^{\circ}$ ANO DO ENSINO FUNDAMENTAL } \\
\hline \multicolumn{2}{|r|}{ EIXO 4: CULTURA E IDENTIDADE } \\
\hline
\end{tabular}


Religare, ISSN: 19826605, v.15, n.1, agosto de 2018, p.97-126.

Subeixos: 1. Culturas, religiões e espiritualidades; 2. Estudo histórico e comparado de religiões no Brasil e no mundo.

Objetivos de aprendizagem

HABILIDADES

1.1 Estudar as definições e relações entre cultura, religiões e espiritualidades.

(EF07ER02) Identificar práticas de espiritualidade utilizadas pelas pessoas em determinadas situações (acidentes, doenças, fenômenos climáticos).

(EF07ER07PA) Identificar e relacionar conceitos sobre cultura, religiões e espiritualidades no contexto amazônico.

2.1 Realizar o estudo histórico e sistemático das religiões no Brasil e no mundo: África, Ásia, Américas, Europa, Oceania.

(EF06ER02) Reconhecer e valorizar a diversidade de textos religiosos escritos (textos do Budismo, Cristianismo, Espiritismo, Hinduísmo, Islamismo, Judaísmo, entre outros)

(EF06ER03) Reconhecer, em textos escritos, ensinamentos relacionados a modos de ser e viver.

(EF06ER04) Reconhecer que os textos escritos são utilizados pelas tradições religiosas de maneiras diversas

(EF06ER05) Discutir como o estudo e a interpretação dos textos religiosos influenciam os adeptos a vivenciarem os ensinamentos das tradições religiosas

(EF07ER05) Discutir estratégias que promovam a convivência ética e respeitosa entre as religiões

(EF07ER04) Exemplificar líderes religiosos que se destacaram por suas contribuições à sociedade

(EF07ER03) Reconhecer os papéis atribuídos às lideranças de diferentes tradições religiosas

(EF07ER08PA) Compreender e respeitar a diversidade cultural religiosa e seus efeitos através dos estudos comparados das religiões no Brasil e no mundo.

ENSINO RELIGIOSO

CICLO 4: $8^{\circ}$ E 9o ANO DO ENSINO FUNDAMENTAL

EIXO 1: O ESPAÇO/TEMPO E SUAS TRANSFORMAÇÕES

Subeixos: As religiões em diversos contextos; 2 . Estudos sobre espiritualidades e novos movimentos religiosos; 3. Concepções seculares da existência humana; 4 . Estudos complementares de religiões: espacialidades e territorialidades religiosas; economia, mercado e marketing religiosos; aspectos e processos naturais da vida religiosa.

\section{Objetivos de aprendizagem}

1.1 Estudar a diversidade e pluralidade cultural religiosa na sociedade brasileira, destacando a realidade paraense.

2.1 Conhecer os novos movimentos religiosos e espiritualidades do mundo contemporâneo, em especial, suas práticas místicas, mágicas e esotéricas.

3.1 Conhecer concepções e orientações de vida secular.

\section{HABILIDADES}

(EF08ER01PA) Compreender e respeitar a diversidade religiosa percebida de várias formas no seu entorno.

(EF08ER02) Analisar filosofias de vida, manifestações e tradições religiosas destacando seus princípios éticos.

(EF08ER02PA) Reconhecer e respeitar as práticas místicas, mágicas e esotéricas presentes nos novos movimentos religiosos e espiritualidades do mundo atual.

(EF09ER01) Analisar princípios e orientações para o cuidado da vida e nas diversas tradições religiosas e filosofias de vida.

(EF09ER03) Identificar sentidos do viver e do morrer em diferentes tradições religiosas, através do estudo de mitos fundantes

(EF09ER01PA) Reconhecer e respeitar os pensamentos e orientações de vida secular, como ateísmo, agnosticismo, materialismo, existencialismo, niilismo, entre outros. 
Religare, ISSN: 19826605, v.15, n.1, agosto de 2018, p.97-126.

\section{ENSINO RELIGIOSO}

CICLO 1: 1ㅜㄹ 2ํㅡㄹ $3^{\circ}$ ANO DO ENSINO FUNDAMENTAL

EIXO 1:O ESPAÇO/TEMPO E SUAS TRANSFORMAÇÕES

Subeixos: 1. Representações religiosas; 2. Religiões locais; 3. Espaços seculares e religiosos; 4. Diversidade religiosa.

\section{Objetivos de aprendizagem}

4.1 Estudar e analisar as relações entre religiões com espacialidades

territorialidades; economia, mercado e marketing religiosos; aspectos e processos naturais da vida religiosa.

\section{HABILIDADES}

(EF09ER02PA) Compreender e analisar de forma crítica e reflexiva a atuação das religiões e espiritualidades nos diversos espaços e setores, destacando a economia, mercado e marketing.

(EF09ER02) Discutir as diferentes expressões de valorização e de desrespeito à vida, por meio da análise de matérias nas diferentes mídias.

\section{ENSINO RELIGIOSO \\ CICLO 4: $8^{\circ}$ E $9^{\circ}$ ANO DO ENSINO FUNDAMENTAL \\ EIXO 2: LINGUAGENS E SUAS FORMAS COMUNICATIVAS}

Subeixos: 1. Textos escritos e orais nas religiões e espiritualidades; 2 . Processos culturais de hibridação, sincretismo, apropriação e adaptação entre religiões e espiritualidades; 3.

Concepções da vida após a morte; 4. Processos e determinações religiosas no pensamento e comportamento.

\section{Objetivos de aprendizagem}

1.1 Conhecer os textos escritos e orais nas religiões e espiritualidades.

2.1 Conhecer e analisar os processos culturais de hibridação, sincretismo, apropriação e adaptação nas religiões e espiritualidades.

3.1 Estudar e analisar as concepções da vida após a morte nas religiões $\mathrm{e}$ espiritualidades.

4.1 Estudar e mostrar como as religiões influenciam na formação do pensamento e comportamento.

\section{HABILIDADES}

(EF08ER03PA) Compreender e analisar a importância dos textos escritos e orais nas religiões e espiritualidades regionais e locais.

(EF08ER01) Discutir como as crenças e convicções podem influenciar escolhas e atitudes pessoais e coletivas.

(EF08ER04PA) Perceber e reconhecer os modos como as culturas, religiões e espiritualidades se misturam.

(EF08ER05) Debater sobre as possibilidades e os limites da interferência das tradições religiosas na esfera pública.

(EF08ER03) Analisar doutrinas das diferentes tradições religiosas e suas concepções de mundo, vida e morte.

(EF09ER03PA) Reconhecer e respeitar as ideias de vida após a morte nas religiões e espiritualidades.

(EF09ER04PA) Reconhecer e refletir sobre as determinações ideológicas de origens religiosas e seculares no pensamento e comportamento humano.

(EF08ER04) Discutir como filosofias de vida, tradições e instituições religiosas podem influenciar diferentes campos da esfera pública (política, saúde, educação, economia).

\section{ENSINO RELIGIOSO}

\section{CICLO 4: $8^{\circ}$ E 9ํㅡㄹ ANO DO ENSINO FUNDAMENTAL}

EIXO 3: VALORES À VIDA SOCIAL

Subeixos: 1. Conflitos, fundamentalismos e fanatismo religioso; 2. Diálogo intercultural: ecumenismo, diálogo inter-religioso, tolerância e intolerância religiosa; 3. Direitos humanos, laicidade e liberdade religiosa; 4 . Religiões e ética: moralidade e valores humanos e religiosos em diálogo.

\section{Objetivos de aprendizagem \\ HABILIDADES}

1.1 Esclarecer as causas de (EF09ER05PA) Esclarecer equívocos sobre conflitos e atitudes 
Religare, ISSN: 19826605, v.15, n.1, agosto de 2018, p.97-126.

\section{ENSINO RELIGIOSO}

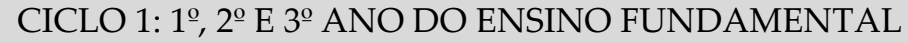

EIXO 1:O ESPAÇO/TEMPO E SUAS TRANSFORMAÇÕES

Subeixos: 1. Representações religiosas; 2. Religiões locais; 3. Espaços seculares e religiosos; 4. Diversidade religiosa.

Objetivos de aprendizagem

conflitos, fundamentalismos

e fanatismos de motivação

religiosa.

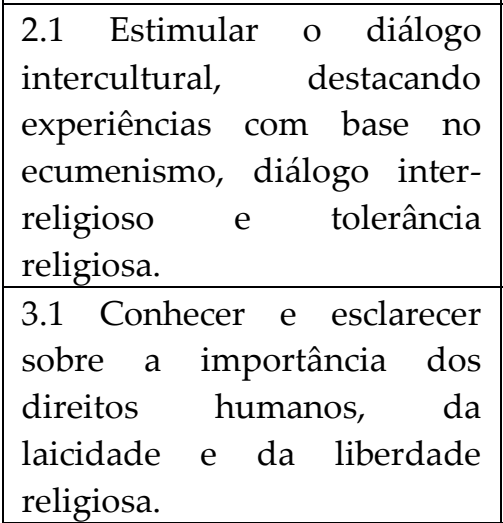

4.1 Estudar e conhecer a relação entre religiões com a ética, moralidade e valores humanos.

sustentadas em motivações fanáticas em diferentes contextos religiosos.

(EF08ER06) Analisar práticas, projetos e políticas públicas que contribuem para a promoção da liberdade de pensamento, crenças e convicções.

(EF08ER07) Analisar as formas de uso das mídias e tecnologias pelas diferentes denominações religiosas.

(EF09ER06PA) Promover e fortalecer atitudes baseadas em experiências de aproximação, diálogo e principalmente de respeito entre as diversas religiões.

(EF09ER07PA) Identificar e respeitar a convivência cidadã com base nos direitos humanos, liberdade religiosa e os limites entre o público e o privado.

(EF08ER05) Debater sobre as possibilidades e os limites da interferência das tradições religiosas na esfera pública.

(EF08ER06PA) Compreender e refletir acerca da importância de uma ética, moral e valores humanos, em diálogo permanente com a visão religiosa.

(EF09ER08) Construir projetos de vida assentados em princípios e valores éticos.

ENSINO RELIGIOSO

CICLO 4: $8^{\circ}$ E $9^{\circ}$ ANO DO ENSINO FUNDAMENTAL

EIXO 4

CULTURA E IDENTIDADE

Subeixos: 1. Estudos históricos e comparados sobre religiões indígenas, africanas e afrobrasileiras; 2. Religiões e sociedade: organização social no contexto das religiões, ideologias religiosas, religiões e espaços públicos;

3. Rituais funerários e práticas lutuosas; 4 . Questões bioéticas, identidade e étnico-racial no contexto das religiões.

\section{Objetivos de aprendizagem}

1.1 Estudar e conhecer as religiões indígenas, africanas e afro-brasileiras como práticas culturais da sociedade brasileira.

2.1 Estudar e destacar o papel das religiões nas ideologias e organizações sociais.

3.1 Conhecer os rituais funerários e a sua relação com as práticas lutuosas.

\section{HABILIDADES}

(EF09ER07) Identificar princípios éticos (familiares, religiosos e culturais) que possam alicerçar a construção de projetos de vida.

(EF08ER07PA) Compreender e respeitar as contribuições das religiões indígenas, africanas e afro-brasileiras para a cultura e identidade local, regional e nacional.

(EF09ER09PA) Analisar e refletir criticamente sobre a influência das religiões na organização social dos sistemas seculares, destacando a produção de ideologias.

(EF08ER04) Discutir como filosofias de vida, tradições e instituições religiosas podem influenciar diferentes campos da esfera pública (política, saúde, educação, economia).

(EF09ER04) Identificar concepções de vida e morte em diferentes tradições religiosas e filosofias de vida, por meio da análise de diferentes ritos fúnebres. 
Religare, ISSN: 19826605, v.15, n.1, agosto de 2018, p.97-126.

ENSINO RELIGIOSO

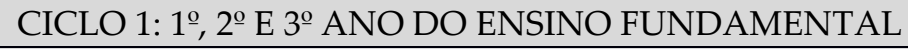

EIXO 1:O ESPAÇO/TEMPO E SUAS TRANSFORMAÇÕES

Subeixos: 1. Representações religiosas; 2. Religiões locais; 3. Espaços seculares e religiosos; 4. Diversidade religiosa.

\begin{tabular}{|c|c|}
\hline Objetivos de aprendizagem & HABILIDADES \\
\hline & (EF09ER10PA) Compreender e respeitar a finalidade dos rituais
\end{tabular}
funerários diante da morte, assim como sua relação direta com o luto, em virtude dos rompimentos de vínculos significativos, perdas, entre outras situações.

4.1 Estudar e conhecer a (EF09ER03) Identificar sentidos do viver e do morrer em influência das religiões nas diferentes tradições religiosas, através do estudo de mitos questões bioéticas, fundantes.

$\begin{array}{lll}\text { identidade e étnico-racial. } & \text { (EF08ER03) Analisar doutrinas das diferentes tradições }\end{array}$ religiosas e suas concepções de mundo, vida e morte.

(EF09ER11PA) Agir e refletir respeitosamente diante das questões bioéticas, identidade e étnico-racial, considerando os limites entre o público e privado, entre o secular e religioso.

\section{Considerações Finais}

Diante de tudo que foi exposto, mesmo que de forma breve, não podemos mais olhar o ER como um componente curricular da escola básica que esteja ausente das discussões e políticas curriculares, pois ao mesmo não the deveria caber nenhuma exceção pedagógica dentro das políticas curriculares.

O ER é sim um componente curricular, que assim como outros sofreu e ainda sofre as consequências da sua trajetória histórica, mas nem por isso estaria condenado ou determinado a ser vítima ou produto disso.

Isso pode ser facilmente percebido pela sua própria evolução curricular apresentada de forma histórico-comparativa, onde sem o devido apoio e responsabilidade dos setores responsáveis as tão urgentes mudanças educacionais não teriam como se concretizar.

Não é de hoje que o Pará tem servido de parâmetro nacional para um ER escolarizado, ao reconhecer essa disciplina acadêmica para a formação inicial e a sua aplicação para o estudo sobre religiões nas escolas públicas.

Nesse processo, a ACREPA tem sido a maior representação efetiva disso, atuando junto com as Secretarias de Educação locais na implantação de 
Religare, ISSN: 19826605, v.15, n.1, agosto de 2018, p.97-126.

currículos embasados teórico-metodologicamente na CR. Essa proposta, embora não seja a versão definitiva da rede estadual, retrata a trajetória desse componente curricular pensado, organizado e executado por licenciados em CR, ou seja, professores de ER.

Essas ações vêm crescendo no Pará e a mais recente notícia que temos é a inclusão de cientistas da religião concursados nos anos iniciais do EF no município de Ananindeua, sendo o primeiro no país a atender a legislação educacional para esse componente curricular em todo o EF.

\section{Referências}

GONZÁLES ARROYO, M. Indagações sobre o currículo: educando e educadores: seus direitos e o currículo. Brasília: MEC/SEB, 2007.

. Currículo, território em disputa. Petrópolis, RJ: Vozes, 2011.

BAHIA, S. F. P.; SANTOS, R. O. As conquistas da ACREPA na efetiva empregabilidade de cientistas das religiões no estado do Pará. In: STERN, F. L.; COSTA, M. O. Ciência da religião aplicada: ensaios pela autonomia e aplicação profissional. Porto Alegre, RS: Editora Fi, 2018, p. 183-196. Disponível em: https://drive.google.com/file/d/1vjsGNgjoRmfMEB9og68KSlf dsNNDNZQ/vie

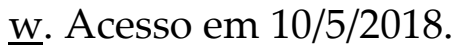

BRANDÃO, C. R. O que é educação. São Paulo: Brasiliense, 2007.

BRASIL. Lei $n^{0}$ 9.475, de 22 de julho de 1997. Brasília, 1997. Publicada no D. O. U., em 23 de julho de 1997.

. Lei $n^{0}$ 9.394. Diretrizes e Bases da Educação Nacional. Sancionada em 20 de dezembro de 1996. Publicada no D. O. U., em 23 de dezembro de 1996.

Resolução $n^{-0}$ 02, de 07 de abril de 1998. Conselho Nacional de Educação. Câmara de Educação Básica. Diretrizes Curriculares Nacionais para o Ensino Fundamental. Brasília, 2008. Publicada no D.O.U., de 15/04/1998, Seção I, p. 31 .

Resolução $n^{\underline{o}}$ 04, de 13 de julho de 2010. Conselho Nacional de Educação. Câmara de Educação Básica. Diretrizes Curriculares Nacionais da Educação Básica. Brasília, 2010. D. O. U., Brasília, 14 de julho de 2010a, Seção 1, p. 824.

. Resolução $n^{-0}$ 07, de 14 de dezembro de 2010. Conselho Nacional de Educação. Câmara de Educação Básica. Diretrizes Curriculares Nacionais para o Ensino Fundamental de Nove Anos. Brasília, 2010. D. O. U., Brasília, 15 de dezembro de 2010b, Seção 1, p. 34. 
Religare, ISSN: 19826605, v.15, n.1, agosto de 2018, p.97-126.

. Parecer CNE/CP $n^{0}$ 15/2017. Anexo: base nacional curricular comum: base é base. Brasília: MEC, 2017a. Parecer homologado pela Portaria no 1.570 , publicada no D.O.U., de 21/12/2017, Seção 1, p. 146.

Resolução $n^{\underline{0}}$ 2, de 22 de dezembro de 2017. Conselho Nacional de Educação. Conselho Pleno. Institui e orienta a implantação da BNCC. Brasília: MEC, 2017b. D. O. U., Brasília, 21 de dezembro de 2017, Seção 1, p. 146.

COSTA, M. O. Diretrizes curriculares nacionais do ensino religioso: uma proposta fundamentada na ciência da religião. In: Ciencias Sociales y Religón/Ciências Sociais e Religião, Porto Alegra, ano 17, n. 23, p. 51-59, ago.-dez. 2015. Disponível

em: http://www.seer.ufrgs.br/index.php/CienciasSociaiseReligiao/article/view/54884 35802, acesso em 30/11/2017.

COSTA, M. O.; STERN, F. L. Metodologias desenvolvidas pela genealogia intelectual da ciência da religião. In: Sacrilegens - Revista dos alunos do programa de pósgraduação em ciência da religião - UFJF, v. 14, n. 1, p. 70-89, jan.-jun./2017. Disponível em: http://www.ufjf.br/sacrilegens/files/2017/12/14-1-6.pdf, acesso em 14/12/2017.

FERNANDES, C. O.; FREITAS, L. C. Indagações sobre o currículo: currículo e avaliação. Brasília: MEC/SEB, 2007.

FONAPER. Fórum Nacional Permanente do Ensino Religioso. Parâmetros curriculares nacionais ensino religioso. São Paulo: Mundo Mirim, 2009.

GOMES, N. L. Indagações sobre o currículo: diversidade e currículo. Brasília: MEC/SEB, 2007.

GRESCHAT, H-J. O que é ciência da religião?. Trad. Frank Usarski. São Paulo: Paulinas, 2005.

HOCK, K. Introdução à ciência da religião. Trad. Monika Ottermann. São Paulo: Loyola, 2010.

LIMA, E. S. Indagações sobre o currículo: currículo e desenvolvimento humano. Brasília: MEC/SEB, 2007.

LOPES, A. C.; MARCEDO, E. Teorias do currículo. São Paulo: Cortez, 2011. Apoio FAPERJ.

LOPES, A. C.; MARCEDO, E. (orgs.). Currículo: debates contemporâneos. 3. ed. Vol. 2. São Paulo: Cortez, 2015.

MÉSZÁRIOS, I. A educação para além do capital. Trad. Isa Tavares. 2. ed. São Paulo: Boitempo, 2008.

MOREIRA, A. F. Indagações sobre o currículo: currículo, conhecimento e cultura. Brasília: MEC/SEB, 2007.

MOREIRA, A. F.; SILVA, T. T. (orgs.). Currículo, cultura e sociedade. 12 ed. São Paulo: Cortez, 2011.

MÜLLER, Max F. Introduction to the science of religion: four lectures delivered at the royal institution in february and may, 1870 [New Edition]. London-UK: Longmans, Green \& Co., 1882 [1870]. 
Religare, ISSN: 19826605, v.15, n.1, agosto de 2018, p.97-126.

PARÁ. Reorientação curricular da rede estadual do Pará. Belém: Secretaria de Estado de Educação. Secretaria Adjunta de Ensino. Diretoria de Educação Infantil e Ensino Fundamental, 2015.

Documento curricular do estado do Pará: documento curricular para a educação infantil e o ensino fundamental do Estado do Pará. Belém, PA: SEDUC/PA, 2018. Versão entregue ao CEE/PA em 08/11/2018.

SANTOS, R. O.; SEIBT, C. L. Ciências da Religião e o Ensino Religioso na Amazônia. In: Revista Pistis \& Praxis: Teologia e Pastoral, Curitiba, v. 6, n. 2, p. 373-397, 2014.

SANTOS, R. O. Proposta curricular do ensino religioso para a educação básica: a experiência do Pará. In: Anais do XII seminário nacional de formação de professores de ensino religioso. FONAPER: Manaus, 2012.

- As abordagens da morte no currículo de formação inicial de professores de ensino religioso no Pará. Belém: Universidade Federal do Pará. Instituto de Ciências da Educação. Programa de Pós-Graduação em Educação. Dissertação de Mestrado, 2014.

Ciências da religião e ensino religioso na região norte: o que e como ensinar? In: Anais do XIII Seminário Nacional de Formação de Professores para o Ensino Religioso. FONAPER: Florianópolis, v 13, 2015, p. 460-466.

Movimento institucional das pessoas favoráveis e contrárias ao ensino religioso. In: BRANDENBURG, L. E.; JUNQUEIRA, S. R. A; KLEIN. R. (orgs.). Compêndio do ensino religioso. São Leopoldo: Sinodal; Petrópolis, RJ: Vozes, 2017, p. 50-62.

. Laicidade e ensino religioso. In: BRANDENBURG, L. E.; JUNQUEIRA, S. R. A; KLEIN. R. (orgs.). Compêndio do ensino religioso. São Leopoldo: Sinodal; Petrópolis, RJ: Vozes, 2017, p. 350-358.

- Ciência da religião aplicada à educação: ensino religioso e educação social. In: Anais do Seminário de Ciência da Religião Aplicada [recurso eletrônico] / org. Fábio L. Stern et al. 2. ed. São Paulo: PUC-SP, 2018, p. 117, p. 88-100. Disponível em: https://drive.google.com/file/d/1vjsGNgjoRmfMEB9og68KSlf dsNNDNZQ/vie

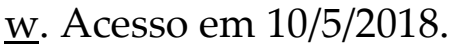

SENA, L. (org.). Ensino religioso e formação docente: ciências da religião e ensino religioso em diálogo. São Paulo: Paulinas, 2006.

SILVA, T. T. Documentos de identidade: uma introdução às teorias do currículo. 3. ed. 10. reimp. Belo Horizonte: Autêntica, 2017.

STERN, F. A criação da área de ciências da religião e teologia na coordenação de aperfeiçoamento de pessoal de nível superior (CAPES). In: Revista Espaços. Instituto São Paulo de Estudos Superiores, 2018 - 26/1.

TEIXEIRA, F. O processo de gênese da(s) ciência(s) da religião na UFJF. In: Numen: revista de estudos e pesquisa da religião, Juiz de Fora, v. 15, n. 2, 2012, p. 537550 .

Disponível

em: 
Religare, ISSN: 19826605, v.15, n.1, agosto de 2018, p.97-126.

https://numen.ufjf.emnuvens.com.br/numen/article/view/2008/1459. Acesso em 15/02/2018.

USARSKI, F. Constituintes da ciência da religião: cinco ensaios em prol de uma disciplina autônoma. São Paulo: Paulinas, 2006. 